\title{
SATISFACTION WITH HUMAN RESOURCE PRACTICES: EVIDENCE FROM BANKING INDUSTRY OF NEPAL \\ Sherjung Khadka*
}

\begin{abstract}
This study is based on quantitative research design. Simple random sampling technique is used in this study. The data were gathered with the help of a well structured questionnaire. Cronbach's alpha was used to test the reliability of the questionnaire. This study is primarily concern with employee satisfaction with HR practices. On an average 77.85 per cent, 73.90 per cent, 87.68 per cent and 71.93 per cent employees satisfied with employee benefits, recruitment and selection, job assignment and performance appraisals respectively and $11.83 \mathrm{per}$ cent, $19.15 \mathrm{per}$ cent, 12.04 per cent, and 21.53 per cent employees neutrally satisfied with these HR practices respectively. Likewise, only 10.32 per cent, 6.95 per cent, 0.28 per cent, and 6.54 per cent employees dissatisfied with the same. Thus, the majority of employees satisfied with HR practices of the banking industry of Nepal.
\end{abstract}

Key words employee benefits, recruitment and selection, job assignment and performance appraisals

\section{INTRODUCTION}

Satisfaction is defined as an individual's reaction to the job experience (Berry, 1997). It is simply how an individual perceived his or her job. It is an essential factor for the success or an organization success. Human Resource (HR) practices such as job security, performance autonomy, employee participation in decision making, salary and benefits, promotion opportunity, career planning opportunity, working conditions, social relations, communication system, recruitment and selection, job assignment, performance appraisals and so on affect employee's satisfaction. In order to achieve organizational success, managers must continuously ensure the satisfaction of their employees. Employee satisfaction has been a key area of concern among managers and executives in the organization. According to Salanova and Kirmanen (2010), there are important reasons why companies should be concerned with employee satisfaction, which can be classified according to the focus on the employee or the organization. First, the humanitarian perspective is that people deserve to be treated fairly and with respect. Satisfaction is the reflection of a good treatment. It also can be considered as an indicator of emotional well-being or psychological health. Second, the utilitarian perspective is that employee satisfaction can lead to behavior by an employee that affects organizational functioning. Scholars and HR professionals generally make a distinction between affective job satisfaction and cognitive job satisfaction. Affective job satisfaction is the extent of pleasurable emotional feelings individuals have about their jobs overall (Thompson and Phua, 
2012) and is different to cognitive job satisfaction which is the extent of individuals' satisfaction with particular facets of their jobs, such as pay, pension arrangements, working hours and numerous other aspects of their jobs (Moorman, 1993). Low turnover, high employee retention, hogh morale, high motivation etc. are the results of employee satisfaction. Organization should take initiation for employee satisfaction. Without satisfaction with HR practices, employee cannot be motivated and committed towards job.

\section{OBJECTIVE OF THE STUDY}

The objective of the study is to evaluate and investigate the employee satisfaction with HR practices of the the banking industry of Nepal.

\section{CONCEPTUAL FRAMEWORK}

Conceptual framework outlines the possible courses of action of the research. It is the foundation on which the study is conducted or established. The present study is related with employees' satisfaction with HR practices of the banking industry of Nepal. As we mentioned above, there are several HR practices but this study covers only employee benefits, recruitment and selection, job assignment and performance appraisals. Employee benefits are compensation paid to an employee for his or her contribution to the organization. It includes direct pay and other benefits like, retirement benefits, medical care benefits, insurance package, ownership benefits, leave benefits; flex working hour benefits and so on. Recruitment is the process of locating, identifying and attracting capable applicants (Robbins and Coulter, 2006) and selection is the process of screening job applicants to ensure that the most appropriate candidates are hired (Ibid). Recruitment and selection ensure right person at right place at right time. Job assignments the process of allocation of works among employees in an organization. It is directly related with employee turnover, retention, motivation and commitment. Employees need comfortable and variety of works. Some employee need new and challenging works and some employees need regular nature of work. Performance appraisal is a formal system of review and evaluation of individual or team task performance (Mondy and Noe, 2006). It is a method by which the performance of an employee is evaluated. Effective appraisal system evaluates accomplishments and initiates plans for development, goals and objectives (Mondy and Noe, 2006). This study attempts employees satisfaction with HR practices.

\section{LITERATURE REVIEW}

Employee satisfaction is an important issue for management and employees in any organizational setting (Volsky and Aguilar, 2009). It is known to have positive impact on employee turnover intentions (Mbah and Ikemefuna, 2012). According to Locke (1976), job satisfaction is a pleasurable or positive emotional state resulting from the appraisal of one's job or job experiences. Similarly, "job satisfaction is the degree of needs satisfaction that is derived from experienced on the job (Dessler, 1978: 37). Likewise, he affirms that "the ability of employees in an organization aspirations, feeling happy doing their job with the hope that their needs will be achieved" (Dessler, 1978: 37). Job security, performance autonomy, employee participation in decision making, salary and benefits, promotion opportunity, career planning opportunity, working conditions, social relations, communication system, recruitment and selection, job assignment, performance appraisals etc. are the major 
dimensions or HR practices of employee satisfaction. According to Armstrong (2006), the key factors affecting employee satisfaction are career opportunities, job influence, teamwork and job challenge. Employee satisfaction with HR practices enhances employee motivation and commitment towards job, such high motivation and high commitment increase employee retention and lower employee turnover. Thus, organizational effectiveness depends on satisfied employees with HR practices. Quantifiable and positive links have been established between job satisfaction and organizational effectiveness (Ostroff, 1992; Koys, 2001). Many researchers conducted studies in the field of employee satisfaction with HR practices. Among them some relevant studies have reviewed in this present article.

Salanova and Kirmanen (2010) conducted a research. The purpose of this research wae to analyze the level of employee satisfaction and motivation. It also dealt with the effect the organizational culture on employee satisfaction. The research reveals that the level of employee satisfaction is high, although there is still a room for improvements. One of the biggest strength of the organization is the relationship and communication between the employees and the managers. The biggest improvement is needed in the field of the financial rewards, because most of the employees are not showing high satisfaction with it. In a study among women working in the private banking sector, Metle (2001) reveals that job satisfaction declines with increasing levels of education (as cited in Volsky and Aguilar, 2009). Metle (2001) argues that higher levels of education tend to increase employee goal and income expectations. Ologunde (2000) finds that satisfaction with the nature of work is negatively related to turnover intention in her sample of University Teachers in South-western Nigeria. Similarly, Koh and Goh (1995) also reveal that satisfaction with the nature of work was negatively associated with turnover intention in their sample of clerical employees in the banking industry. Men and women working in gender-balanced groups have higher levels of job satisfaction than those who work in homogeneous groups. Employees who work in groups comprised of mostly men tend to show the lowest levels of job satisfaction and those working in groups of mostly women fall in the middle of the gender-balanced and mostly-men groups (Fields and Blum, 1997, as cited in Volsky and Aguilar, 2009). Pook, Fustos and Marian (2003) surveyed 932 employees in Eastern Europe to explore the impact of gender bias on job satisfaction. Results suggest that women are less likely to receive help from their managers toward advancement and are less satisfied than men with the work they performed. This may be the result of being assigned less-challenging tasks, non-commensurate with their backgrounds (as cited in Volsky and Aguilar, 2009). A study reveals that (i) the higher the satisfaction with supervision the lower the employee turnover intention, (ii) the higher the satisfaction with nature of work the lower the employee turnover intention, and (iii) the higher the satisfaction with pay, the lower the employee turnover intention (Mbah and Ikemefuna, 2012). Similarly, Mobley, Griffeth, Hand, and Meglino (1979) reveal that age, tenure, overall satisfaction, job content, intentions to remain on the job and commitment were all negatively related to turnover. Behera, Sahoo, and Sundaray (n. d.) suggest the various factors which influence job satisfaction. It has been observed that if managers do not pay attention to these factors, it is likely to result in job dissatisfaction and ultimately may result in employee turnover. The results showed a significant negative correlation between job satisfaction and turnover intentions. This signifies that higher the job satisfaction, lower is the intent of a person to quit the job (Randhawa, 2007). Similarly, Hellman 
(1997) conducted a meta-analysis and found the relationship between job satisfaction and intent to leave was significantly different from zero and consistently negative. Employee satisfaction has been found to be positively related to the intent to remain with the company (Light, 2004). Low absenteeism is associated with high job satisfaction while high turnover and absenteeism are said to be related to job dissatisfaction (Saifuddin and Sermsri, 2008).

\section{RESEARCH METHODOLOGY}

Research methodology is a process of gathering, recording, analyzing, and interpreting the data. It is a way to systematically solve the research problem; it may be understood as a science of studying how research is done scientifically (Reseapro, 2013). Research methodology of present study consists of research design, population and sampling, data collection and reliability of the questionnaire.

\section{RESEARCH DESIGN}

For the purpose of this study, a quantitative research strategy was followed. The intention of quantitative research is first, to predict, describe and elucidate quantities, degrees and relationships and secondly, to generalise from a sample to the relevant population via the collection of statistical data (Du Plooy, 2002). Quantitative research relies on measurement to compare and analyse different variables (Bless, Higson-Smith and Kagee, 2000). The philosophical worldview or an ontological assumption of this study regarding employee satisfaction is single reality not multiple realities and the epistemological assumption of this study is objective not subjective. It involves counting and measuring of events and performing the statistical analysis of a body of numerical data (Smith, 1988). Quantitative research is defined as social research that employs empirical methods and empirical statements (Cohen, 1980). It adopts a scientific approach and focuses on measurement and proof. It is based on the premise that something is meaningful only if it can be observed and counted (Hesketh and Laidlaw, n. d.). It refers to the systematic empirical investigation of social phenomena via statistical, mathematical or computational techniques (Lisa, 2008).

\section{PopUlation AND SAMPLING}

The present study has covered all commercial banks of Nepal. There are 31 commercial banks in Nepal. These banks have 1245 branches and 22,402 employees (Bank Supervision Report, 2011). Thus, the population of this study is 22,402 employees working in 1245 branches of 31 commercial banks of Nepal. The present study used simple random sampling technique, in which every employee of the total population i.e. 22,402 chance of being chosen, in order to evaluate and analyze the employee satisfaction in the banking industry of Nepal. The sample size is 397. It was calculated by using formula purposed by Yamane (1967).

\section{DATa Collection}

The major tool of data collection for the present study was well structured survey questionnaire. Apart from this, keeping in mind the purposes of the study, multiple sources of data were used in the present study. The researcher visited several libraries, banks, Planning Commission, Nepal Stock Exchange, Nepal Rastra Bank, Central Bureau of Statistics, Bankers' Association, Ministry of Finance, and many more places for the purpose of procuring relevant documents during the course of secondary data collection for this research study. The researcher also used several related journals, e-journals, and websites. 


\section{RELIABILITY OF THE QUESTIONNAIRE}

The researcher has used Cronbach's alpha to test the reliability of the questionnaire because it is one of the important tools used in testing the reliability of the instruments in a research. Here, Cronbach's alpha values of four variables are: 0.905 for employee benefits, 0.938 for recruitment and selection, 0.845 for job assignment, and 0.888 for performance appraisals.

\section{RESULTS AND DISCUSSION}

The survey questionnaire has consisted of 16 questions. The questions were aimed at evaluating how employees perceived their level of job satisfaction in the areas of employee benefits, recruitment and selection, job assignment and performance appraisals. The results to this set of job satisfaction factors are displayed in below mentioned figure.

\section{EMPLOYEE BENEFITS}

In order to evaluate and investigate how employees perceive employee benefit as a job satisfaction factor, they were requested to respond to following four statements: my salary is satisfactory to me, bank provides bonus to me (if it earns profits), I am satisfied with retirement benefits provided to me by bank and I am satisfied with leave provided to me by the bank. The majority of employees agreed (65.2\%) and strongly agreed $(13.9 \%)$ with the first statement. The employee disagreed $(8.5 \%)$ and strongly disagreed $(2.5 \%)$ and remained neutral $(10.0 \%)$ with the same. Thus, it can be concluded that the employees were satisfied with their salary. Similarly, the majority of employees agreed (60.7\%) and strongly agreed (10.4\%) with the second statement. The employee disagreed $(4.0 \%)$ and strongly disagreed $(2.5 \%)$ and remained neutral (22.4\%) with the same. It means employees were satisfied with bonus provided to them by the banking industry of Nepal. Likewise, about employees agreed (60.7\%) and strongly agreed (8.5\%) with the third statement and disagreed (16.4\%) and strongly disagreed $(2.0 \%)$ and remained neutral $(12.4 \%)$ towards this statement or the retirement benefits. The proportion of agreed is greater than disagreed, thus it can be concluded that the employees of the banking industry were satisfied with retirement benefits. Finally, the majority of employees agreed (66.2\%) and strongly agreed (26.4\%) with the last statement. The employee disagreed (3.5\%) and strongly disagreed $(1.5 \%)$ and remained neutral $(2.5 \%)$ with the same. It means the employees were found positive with the leave facilities provided by the banking industry of Nepal.

\section{Recruitment and Selection}

The next set of job satisfaction factors is recruitment and selection. In order to evaluate and investigate how employees perceive recruitment and selection as a job satisfaction factor, they were requested to respond to following four statements: my bank employs systematic selection process, my bank selects right person at right place, my bank selects right person at right time and in my opinion, there is no nepotism in the selection process. The majority of employees agreed $(57.2 \%)$ and strongly agreed $(25.9 \%)$ with the first statement. The employee disagreed $(2.0 \%)$ and strongly disagreed $(1.0 \%)$ and remained neutral $(13.9 \%)$ with this statement. The employees were found positive with selection process of the organization. Accordingly, the responses to the second statement were also positive, with 57.2 per cent of the employees who agreed and 21.9 per cent who strongly agreed with this statement. However, it must be noted that 6.0 per cent of the employees did not agree 
with this statement and 14.9 per cent remained neutral with the same. In the same way, more than average employee agreed (51.7\%) and strongly agreed (17.9\%) with the third statement. The employee disagreed (9.5\%) and strongly disagreed $(2.0 \%)$ and remained neutral $(18.9 \%)$ with the same. It means employees were found positive with the recruitment and selection policy of the banking industry of Nepal. Eventually, the responses to the statement regarding there is no nepotism in the selection process indicate that 47.3 per cent agreed and 7.5 per cent of the employees strongly agreed. However, it must be noted that the responses were less positive, with 16.4 per cent of the having indicated that they disagreed with the statement.

\section{Job Assignment}

Another set of job satisfaction factors is job satisfaction. In order to evaluate and investigate how employees perceive job assignment policy of the banking industry of Nepal as a job satisfaction factor, they were requested to respond to following four statements: my bank assigns job according to capacity, I have full autonomy to perform my works, my work is clearly defined and I have given opportunities to learn different kinds of works. The majority of employees agreed (65.7\%) and strongly agreed (12.9\%) with the first statement. The employee disagreed (3.5\%) and strongly disagreed $(0.5 \%)$ and remained neutral $(17.4 \%)$ with this statement. The employees were found positive with this statement. The study revealed that the majority employees agreed $(75.1 \%)$ with the second statement and employees strongly agreed (12.9\%) with the same. In other side, nobody strongly disagreed with the statement and employees disagreed $(1.5 \%)$ with the same. It means, the proportion of agreed with this statement is more than that of disagreed with the same. Therefore, it can be concluded that the employees were satisfied with the statement on the average despite the fact that 10.4 per cent employees showing neutral satisfaction towards the statement. Similarly, the majority employees $(94.5 \%)$ felt that their work is clearly defined, only 1.5 per cent employees disagreed with this statement and 4.0 per cent remained neutral with the same. The disagreement to this statement may be because some of the jobs are very closely related and are also, to a large degree, very dependent on each other. Accordingly, the majority of employees agreed $(68.7 \%)$ and strongly agreed $(10.9 \%)$ with the last statement. About 4.0 per cent employees disagreed and 16.4 per cent remained neutral with this statement. Thus, the employees of the banking industry of Nepal were found positive with this statement.

\section{Performance Appraisals}

The last set of job satisfaction factors is performance appraisals. In order to evaluate and investigate how employees perceive performance appraisals of the banking industry of Nepal as a job satisfaction factor, they were requested to respond to following four statements: my manager appraises my performance on regular basis, my performance appraisals are based on predetermined standards, my manager appraises my performance without biasness, and I have got feedback of my performance from my manager. In this set, 67.7 per cent of employees agreed and 5.5 per cent strongly agreed first statement. The responses also indicate that 7.5 per cent of the employees agreed and 1.0 per cent strongly agreed and 18.4 per cent remained neutral with this statement. Thus, the employees of banking industry of Nepal were positive with this statement. Likewise, the responses to the second statement were also positive, with 64.7 per cent of the employees who agreed and 5.0 per cent who strongly agreed with this statement. However, it must be noted that 8.0 per cent of the 
employees did not agree with this statement and 22.4 per cent remained neutral with the same. Therefore, it can be concluded that the employees were satisfied with the statement because the proportion of agreed with this statement is more than that of disagreed with the same. In the same way, more than average employee agreed $(52.2 \%)$ and strongly agreed $(3.0 \%)$ with the third statement. The employee disagreed $(9.5 \%)$ and strongly disagreed $(0.5 \%)$ and remained neutral $(36.8 \%)$ with the same. It means employees were found positive with this statement. Lastly, the responses to the statement regarding feedback on performance indicate that 84.1 per cent employees agreed and 5.5 per cent employees strongly agreed. However, it must be noted that the responses were less positive, with 4.0 per cent of the employees having indicated that they disagreed with the statement. Therefore, it can be concluded that the employees were satisfied with the statement despite the fact that 8.50 per cent are showing neutral satisfaction towards the statement.

In conclusion, this study is primarily concern with employee satisfaction with HR practices such as employee benefits, recruitment and selection, job assignment and performance appraisals. On an average 77.85 per cent, 73.90 per cent, 87.68 per cent and 71.93 per cent employees satisfied with employee benefits, recruitment and selection, job assignment and performance appraisals respectively and 11.83 per cent, 19.15 per cent, 12.04 per cent, and 21.53 per cent employees neutrally satisfied with these HR practices respectively. Likewise, only 10.32 per cent, 6.95 per cent, 0.28 per cent, and 6.54 per cent employees dissatisfied with the same. Thus, the majority of employees satisfied with HR practices of the banking industry of Nepal.

\begin{tabular}{|l|c|c|c|c|c|}
\hline \multicolumn{1}{|c|}{ Statements } & $\begin{array}{l}\text { Strongly } \\
\text { disagree }\end{array}$ & Disagree & Neither & Agree & $\begin{array}{c}\text { Strongly } \\
\text { agree }\end{array}$ \\
\hline My salary is satisfactory to me & 2.5 & 8.5 & 10.0 & 65.2 & 13.9 \\
\hline Bank provides bonus to me & 2.5 & 4.0 & 22.4 & 60.7 & 10.4 \\
\hline $\begin{array}{l}\text { I am satisfied with retirement benefits } \\
\text { provided to me by bank }\end{array}$ & 2.0 & 16.4 & 12.4 & 60.7 & 8.5 \\
\hline $\begin{array}{l}\text { I am satisfied with leave provided to } \\
\text { me by the bank }\end{array}$ & 1.5 & 3.5 & 2.5 & 66.2 & 26.4 \\
\hline My bank employs systematic selection process & 1.0 & 2.0 & 13.9 & 57.2 & 25.9 \\
\hline My bank selects right person at right place & 1.5 & 4.5 & 14.9 & 57.2 & 21.9 \\
\hline My bank selects right person at right time & 2.0 & 9.5 & 18.9 & 51.7 & 17.9 \\
\hline $\begin{array}{l}\text { In my opinion, there is no nepotism in } \\
\text { the selection process }\end{array}$ & 5.0 & 11.4 & 28.9 & 47.3 & 7.5 \\
\hline My bank assigns job according to capacity & 0.5 & 3.5 & 17.4 & 65.7 & 12.9 \\
\hline I have full autonomy to perform my works & 0.0 & 1.5 & 10.4 & 75.10 & 12.9 \\
\hline My work is clearly defined & 0.0 & 1.5 & 4.0 & 77.6 & 16.9 \\
\hline $\begin{array}{l}\text { I have given opportunities to learn } \\
\text { different kinds of works }\end{array}$ & 0.0 & 4.0 & 16.4 & 68.7 & 10.9 \\
\hline $\begin{array}{l}\text { My manager appraises my } \\
\text { performance on regular basis }\end{array}$ & 1.0 & 7.5 & 18.4 & 67.7 & 5.5 \\
\hline $\begin{array}{l}\text { My performance appraisals are based on } \\
\text { predetermined standards }\end{array}$ & 1.5 & 6.5 & 22.4 & 64.7 & 5.0 \\
\hline $\begin{array}{l}\text { My manager appraises my } \\
\text { performance without biasness }\end{array}$ & 0.5 & 7.0 & 36.8 & 52.2 & 3.5 \\
\hline $\begin{array}{l}\text { I have got feedback of my } \\
\text { performance from my manager }\end{array}$ & 0.0 & 2.0 & 8.5 & 84.1 & 5.5 \\
\hline
\end{tabular}

\section{CONCLUSIONS}


The present study entitled 'Satisfaction with HR practices: Evidence from banking industry of Nepal' was divided in five topics namely introduction, literature review, research methodology, results and discussion and conclusion. The study revealed that 79.1 per cent of employees satisfied with the present salary in the banking industry of Nepal. This result is consistent with the study of Salanova and Kirmanen (2010). The results show that 13.9 per cent employees strongly agreed with their salary and 65.2 per cent employees agreed with the same. In other side, 2.5 per cent employees strongly disagreed with their salary and 8.5 per cent employees disagreed with the same. The study also revealed that the majority $(60.7 \%)$ of employees agreed with the statement 'bank provides bonus to me (If it earns profits)' and 10.40 per cent strongly agreed with the statement. Thus, employees also found satisfied with bonus provided to them by the banking industry of Nepal. The study also revealed that 60.7 per cent employees agreed, 8.5 per cent strongly agreed, 12.4 per cent neither, 16.4 per cent disagreed and remaining 2.0 per cent employees strongly disagreed with the statement 'I am satisfied with retirement benefits provided me by bank'. It indicates that majority of employees satisfied with retirement benefits. The majority of employees $(92.4 \%)$ satisfied with the leave provided to them by the bank. The results show that 66.2 per cent employees agreed and 26.40 per cent employees strongly agreed with the statement. Most of employees of banking industry of Nepal satisfied with the employee selection process of the bank. The research revealed that 57.2 per cent employees agreed and 25.90 per cent employees strongly agreed with the statement related with employee selection process. The majority of banking employees (79.1\%) satisfied with the statement 'my bank selects right person at right place'. The results indicate that the 57.2 per cent employees agreed and 21.9 per cent employees strongly agreed with the statement. The study found that 51.7 per cent employees agreed and 17.9 per cent employees strongly agreed, 18.9 per cent neither, 9.5 per cent disagreed and remaining 2.0 per cent employees strongly disagreed with the statement 'my bank selects right person at right time'. It indicates that more than average employees satisfied with selection of right person at right time. The result shows that 7.5 per cent employees strongly agreed with the statement'there is no nepotism in the selection process' and 47.3 per cent employees agreed with the same. In other side, 5.0 per cent employees strongly disagreed with the statement and 11.40 per cent employees disagreed with the same. The employees of banking industry of Nepal were found satisfied with the job assignment. The study revealed that the 65.7 per cent employees agreed and 12.9 per cent employees strongly agreed with the job assignment related statement.

The majority of employees $(88.0 \%)$ satisfied with the statement 'I have full autonomy to perform my work'. The study showed that 75.1 per cent employees agreed and 12.90 per cent employees strongly agreed with the statement. The result shows that 16.9 per cent employees strongly agreed with the statement- 'my work is clearly defined' and 75.1 per cent employees agreed with the same. In other side, there was nobody strongly disagreed with the statement and 1.5 per cent employees disagreed with the same. The majority of employees $(79.60 \%)$ satisfied with the given opportunities to learn different kinds of works. The results show that the 68.7 per cent employees agreed and 10.90 per cent employees strongly agreed with the learning opportunities provided by the bank. More than average employees of banking industry of Nepal satisfied with the performance appraisal intervals. The study 
revealed that the 67.7 per cent employees agreed and 5.50 per cent employees strongly agreed with performance appraisal intervals of the bank. Similarly, more than average employees satisfied with the statement 'my performance appraisals are based on predetermined standards'. About 64.7 per cent and 5.0 per cent employees agreed and strongly agreed with the statement respectively. The study revealed that 3.0 per cent employees strongly agreed and 52.5 per cent agreed with the statement 'my manager appraises my performance without biasness'. It indicates that the majority of employees satisfied with the statement. The majority of employees (89.6\%) satisfied with the statement ' $I$ have got feedback of my performance from my manager'. The results show that the 84.1 per cent employees agreed and 5.5 per cent employees strongly agreed with the statement.

\section{WORKS CITED}

Armstrong, M. (2006). A handbook of human resource management practices $\left(10^{\text {th }}\right.$ ed.). Cambridge University Press, United Kingdom.

Bank Supervision Department (2011 July). Bank supervision report. Nepal Rastra Bank, Nepal.

Behera, N., Sahoo, C.K., and Sundaray, B.K. (n.d.). Retaining high performing employees through job satisfaction: A theoretical construct. Online: http://www.dspace.nitrkl.ac.in, Retrieved on May 13, 2012.

Berry, L.M. (1997). Psychology at work. San Francisco: McGraw Hill Companies Inc.

Cohen, L., and Manion, L. (1980). Research methods in education. Groom Helm Ltd., London.

Dessler, G. (1978). Personnel management: Modern concept and techniques. Renton Publishing Company Inc., Virginia.

Fields, D., and Blum, T.C. (1997). Employee satisfaction in work groups with different gender composition. Journal of Organizational Behavior, 18, 181-196.

Hellman, C.M. (1997). Job satisfaction and intent to leave. Journal of Social Psychology, 137 (6), 677-689.

Hesketh, E.A., and Laidlaw, J.M. (n.d.). Quantitative research. Designed and produced by the Education Development Unit, NHS Education for Scotland Initial Development sponsored by the Scottish Higher Education Funding Council.

Koh, H.C. and Goh, C.T. (1995). An analysis of the factors affecting the turnover intention of non-managerial clerical staff: A Singapore study. The International Journal of Human Resource Management, 6 (1).

Light, J. N. (2004). Relationships and effects of employee involvement, employee empowerment and employee satisfaction by job-type in a large manufacturing environment. A dissertation presented in partial fulfillment of the requirement for Degree of Doctor of Philosophy, Capella University.

Lisa, M. (2008). The Sage encyclopedia of qualitative research methods. Sage Publications., Los Angeles, Calif. ISBN 1-4129-4163-6. 
Locke, E.A. (1976). The nature and causes of job satisfaction. Handbook of Industrial and Organizational Psychology. 1297-1349.

Mbah, S.E. and Ikemefuna, C.O. (2012, Special Issue-July). Job satisfaction and employees' turnover intentions in total Nigeria plc. in Lagos State. International Journal of Humanities and Social Science, 2(14).

Metle, M.K. (2001). Education, job satisfaction and gender in Kuwait. International Journal of Human Resource Management. 12, 311-32.

Mobley, W.H., Griffeth, R.W., Hand, H.H. and Meglino, B.M. (1979). Review and conceptual analysis of the employee turnover process. Psychological Bulletin. 86 (3), 493-522.

Mondy, F.W., and Noe, R.M, (2006). Human resource management. Pearson Education Inc., Delhi.

Moorman, R.H. (1993). The influence of cognitive and affective based job satisfaction measures on the relationship between satisfaction and organizational citizenship behavior. Human Relations. 6, 759-776.

Ologunde, A.O. (2000). Motivation and labor turnover among university teachers in Southwest Nigeria. Unpublished M. Phil Thesis, Department of management and Accounting. Obafemi Awolowo University, IleIfe, Nigeria.

Ostroff, C. (1992). The relationship between satisfaction, attitudes, and performance: An organizational level analysis. Journal of Applied Psychology. 77(6), 963-974.

Pook, L.A., Fustos, J., and Marian, L. (2003). The impact of gender bias on job satisfaction Components of job satisfaction and advancement in postliberation Hungary, Poland, and Romania. Human Systems Management. 22(1), 37-50.

Randhawa, G. (2007). Relationship between job satisfaction and turnover intentions: An empirical analysis. Indian Management Studies Journal. 11, 149-159.

Robbins, S.P., and Coulter, M. (2006). Management. Prentice-Hall of India Private Limited, New Delhi.

Salanova, A., and Kirmanen, S. (2010). Employee satisfaction and work motivation. Bachelor's Thesis, Business Management, Mikkeli University of Applied Sciences.

Smith M.J. (1988). Contemporary communication research methods. Wadsworth, Inc., Belmont, CA.

Thompson, E.R. and Phua, F.T. (2012). A brief index of affective job satisfaction. Group and Organization Management. 37 (3), 275-307.

Vlosky, R.P. and Aguilar, F.X. (2009). A model of employee satisfaction: Gender differences in cooperative extension. Journal of Extension. Available on: www.joe.org. 